\title{
Tourism and the Sharing Economy. An Evidence from Airbnb Usage in Italy and Romania*
}

\author{
Maurizio Cesarani ${ }^{* *}$, Florin Nechita***
}

\begin{abstract}
Tourism in the era of the sharing economy adopts a model based on a global concept with a local practice. The traditional tourism offer is based on the attractiveness of a destination, expressed by a system of characteristics of the destination itself and a range of services related to accommodation, transport and food. The tourism model of sharing economy, instead, is based on the development of shared services that stimulate the flows of tourists. Traditional destinations are then alongside new destinations that, thanks to some factors that drive the development of sharing economy platforms, attract tourists, change behaviours and modify competitive dynamics. The new paradigm of could be briefly described by the 4 Ts of sharing economy: Trust, Togetherness, Technology and Transformation.
\end{abstract}

Keywords: Global Tourism; Sharing Economy; Sharing Platform; Hospitality; Accommodation; Global Markets; Global Competition

\section{Tourism and the Sharing Economy}

Sharing is a phenomenon as old as humankind is, while collaborative consumption and the 'sharing economy' are phenomena born of the Internet age (Belk, 2014). Several definition of the sharing economy have been given, both from academics and from practitioners. A very broad definition is suggested by The People Who Share, a campaigning group promoting the sharing economy: "The sharing economy is a socio-economic ecosystem built around the sharing of human and physical resources. It includes the shared creation, production, distribution, trade and consumption of goods and services by different people and organisations". In contrast, a quite narrow definition from a more academic world attempts to define the sector more closely by arguing a) it should only include consumer-to-consumer transactions, not business-to-consumer transactions, b) the sharing economy should be understood to only include transactions where consumers provide temporary access to a good, not the permanent transfer of

\footnotetext{
* The Authors: M. Cesarani $\S \S 1,2,3,3.1$; F. Nechita $\S \S 1,3.2,4$.

** Research Fellow in Management, University-of Milan-Bicocca (maurizio.cesarani@unimib.it)

*** Lecturer in Marketing, Advertising and Branding, Transilvania University of Brașov (florin.nechita@unitbv.ro)
}

Edited by: ISTEI - University of Milan-Bicocca

ISSN: 1593-0319

Cesarani, M. \& Nechita, F. (2017). Tourism and the Sharing Economy. An evidence from Airbnb Usare in Italy and Romania, Symphonya. Emerging Issues in Management (symphonya.unimib.it), $3,32-47$. 
ownership of the good, c) it should only include transactions regarding physical assets (Frenken et al, 2015).

Therefore, a more specific analysis can be based on a new and tailored definition of the sharing economy. In its research for the European Parliament, Europe Economics defines the sharing economy as "the use of digital platforms or portals to reduce the scale for viable hiring transactions or viable participation in consumer hiring markets (i.e. 'sharing' in the sense of hiring an asset) and thereby reduce the extent to which assets are under-utilised".

In other words, a recent definition of the sharing economy describes it as a set of practices, models and platforms that, through technology and community, allows individuals and companies to, at least partly, share access to products, services and experiences. It includes non-profit and for-profit platforms that have emerged from an originally pure sharing economy, peer-to-peer and/or non-profit organisations (Weston, 2015).

Overall, from a theoretical point of view, sharing economy represents a model based on the use of a good or service rather than on the purchase of the same, through a form of temporary possession, which replaces the classical form of ownership. In other words, the sharing economy represents a transition from traditional individual ownership of most assets towards accessibility-based economic models, which can be observed across a wide and increasing variety of markets.

Two trends can be observed in the evolution of this rental-like model. Firstly, technological progress allows this new business model to spread to more and more markets and become more and more convenient and flexible. Secondly, there is a shift to a peer-to-peer accessibility based business model, centred on companies that operate through an online platform or marketplace that connects consumers owning certain assets and skills with consumers in temporary need of them (Goudin, 2016).

It is therefore possible to identify three four main aspects characterising the sharing economy, and these could be concentrated in the 4 Ts of the sharing economy:

- Trust for sharing of human and physical resources

- Togetherness created through peer-to-peer relationship

- Technology platform

- Transformation of the traditional producer - consumer relationship/roles.

The first element, the very nature of the sharing economy itself, is the sharing of human and physical resources, i.e. professionals and privates putting together tangible and intangible assets in a common and shared network. All these could happened because of new mechanisms of building trust between the members of the shared network that create together a new form of capital, reputational capital, where the currency of the new economy is the trust (Botsman, 2012). For example, on Airbnb is required a photo identification and the access to the platform have to be made using Facebook or Google+ accounts or the email.

The second element that regulates relations among the actors involved in the system, is togetherness created through the peer-to-peer relation; an equal relationship where all the actors have the same possibilities to access the good/services, and the value is created with a common effort. The concept of equal 
relationship can be seen, as first, in the interactions among the users of the good/service, which are not segmented based on socio-demographic variables or depending on the purchasing power, but they are only considered with regard to their same chance to access the shared resources. In the case of 'pure' sharing economy, the actors detaining the products are at the same time the users of the same products, involved altogether in a mutual relation. The hosts and guests interaction, followed by sharing their experience through the systems of mutual reviews manage to create a brand and its identity (Yannopoulou et al., 2013). In the particular case of the Airbnb it worth to evoke the answer of its director of product, Vlad Loktev about how the company can be defined, technology or travel company. "We're more of a community company" was the answer (The Economist, 2017).

The third element is the existence of a technological platform that allows the relationship within the system. From a classical point of view, the platform represents the meeting point of demand and supply, overcoming the traditional distinction that sees the demand side related to the consumer and the supply side linked with the firms. In a peer-to-peer system, based on the sharing of goods and services, the role of the firm is modified: it no longer represents the supplier of the good/service, but rather represents the medium that put together, thought a platform, many private citizens, holders and users at the same time of a specific product. According to Tauscher and Laudien (2017), as a business model Airbnb represent a peer-to-peer offline service that aim to connect people to list, discover, and book private accommodation and its value proposition is "novel services with community feeling within and outside digital platform".

The fourth element of the sharing economy resides in the way that newly created relationships in this new form of the economy transform both producers and consumers. For example, the roles of host and guests, producer and consumer, become blurred and platforms like Airbnb can be viewed not just as hospitality companies, but as new "sectors" creating demand for niche services (J. Walter Thompson Intelligence, 2015). In the same time, both guests and hosts are encouraged to continuos improve their behovior or product/service, respectively in order to become better rated in the network. Gamification techniques are used in order to stimulate this positively transformation, as hosts are stimulated to become superhosts (Airbnb, 2017). Transformation affects not only hosts, guests and relationship between them, because it can enrich destination attributes and add to the competitiveness of destinations (Tussyadiah \& Pesonen, 2015). Another aspect of the transformation of the destination could be viewed from a socio-spatial point of view, as sharing spaces may increase the tourism gentrification process (Gotham, 2005) and Airbnb contribute to the expansion of the historic centres (Neuts \& Nijkamp, 2012).

\subsection{Traditional Tourism Vs Sharing Tourism}

The sharing economy is a fact. It is likely to increase in importance in developed countries. It affects the tourism industry, as many sharing economy platforms are tourism related. The sharing economy has advantages and disadvantages to global competitiveness, seasonality, sustainability, accessibility.

In the traditional tourism model, the attractiveness of a destination is defined according to the characteristics of the destination itself, which are related to a series 
of services that develop as a result of those same characteristics. 'Ancillary' services can be grouped in three categories: accommodation, transport, food.

The traditional form of accommodation is primarily represented by hotels and residences together with campsites; farmhouses; youth hostels; and bed-andbreakfasts. Traditional means of transport include public transport and taxis. Food supply is generally devolved not only to restaurants and bars but also to grocery stores and supermarkets.

On the other hand, in the sharing tourism model it is the presence of sharing platforms regarding accommodation, transport and food that stimulate the development of a destination, especially urban ones, growing attractiveness.

It is notable, indeed, that big cities attract more sharing services compared to small villages. This phenomenon goes together with the growing urbanisation and the move of many people from the countryside to urban contexts worldwide.

Big cities have indeed the strength and the power to attract investments and innovation. The level of aggregation of knowledge production and intangible consumption classifies large conurbations with unconventional metrics, establishing new types of scales for 'world cities' (Brondoni, 2011).

"The sharing economy is fundamentally an urban phenomenon. The platforms that enable sharing leverage or confront conditions of density, proximity, specialisation, and even anonymity that mark city life" (Davidson \& Infranca, 2016).

Analysing the accommodation alternatives, i.e. hotels vs sharing platforms, several researches have been conducted about this relation and there is still room for further investigations. At first, "hotel chains [...] paid little attention to the spread of the sharing economy and only after the rapid growth of platforms such as Airbnb did they recognize the importance of such alternative hospitality service provisions" (Salvioni, 2016). In this sense, hotels should not try to compete on the price, but rather focus on other features. As stated by Cusumano (2015), "traditional hotels can compete by providing a type and level of service that Airbnb cannot match at any price", especially with regards to major events and conventions, as well as to loyalty programs and discounts. However, the impact of the Airbnb on price of the hotels could be observed in limiting the price premium during peak periods (Lane \& Woodworth, 2016). There was studies on Airbnb phenomenon viewed from two perspectives - customers and competitors - and resulted that hotel industry should be more proactive, and, in the same time, "lawmakers will need to move fast to enact legislation to ensure that customers are protected in this tug-of-war between the hotel industry and innovations such as Airbnb" (Varma et al., 2016).

Another option for hotels to stay competitive is the launch of "branded marketplace platforms [that] would be backed by the hotel chain's brand, resources, knowledge, and expertise". While there is a revenue opportunity for hotel chains to incorporate the sharing economy into their business models, this approach poses interesting questions about the ability of hotels to extend their brand by developing their own 'branded marketplace' platform (Richard \& Cleveland, 2016). The challenge hotel chains face is transferring their brand, knowledge, and resources from their current model to the more disruptive sharing economy model. Disruptive innovation concept was introduced by Christensen more than 20 years ago, and it referred at the products/services that ar cheaper, simpler, smaller, and more convenient than the incumbent products (Christensen et al., 2015) Airbnb was 
generally expected to outperform budget hotels/motels, underperform upscale hotels, and have mixed outcomes versus mid-range hotels, signalling - but not complete - consistency with the concept of disruptive innovation (Guttentag \& Smith, 2017). On the other hand, an aspect that must be considered is that "direct host-guest relationships [...] contribute to a higher level of perceived authenticity of tourism experiences" (Dredge \& Gyimòthy, 2015), which is one of the main strength of a sharing platform and may be hardy replicable by a hotel chain. "Living like a local" is the key driver of the authenticity that Airbnb (or other similar platforms) promise, and "experience co-creation is certainly an enabler of these feelings of authenticity" (Paulauskaite et al., 2017).

\section{Sharing Economy and Tourism: Main Drivers}

For several decades, the reasons that influenced a person's decision to plan a holiday have remained essentially the same: a desire to visit new places, to relax and to get away from daily and working routines. And up until now, mass tourism has satisfied this need, offering tourists opportunities for enjoying new experiences as spectators. Tourism and travel is the human activity where Pine and Gilmore (1998) concept of the experience economy is best illustrated. In time, however, tourists have greatly refined their taste and their expectations; and their reasons for travelling have changed accordingly. The 'new' tourist is increasingly looking for a meaningful personal experience, and is therefore striving to be engrossed by his/her trip, to feel completely engaged, aiming for memorable and unique experiences (Forno \& Garibaldi, 2015).

Together with this shift in the traditional reasons for travelling, some main drivers that support the development of sharing economy in the field of tourism, emerges:

- The Great Recession

- Digital Payments

- Smartphone Adoption

- Community Culture

- Airbnb's Success

The Great Recession represent the first driver that pushed sharing economy alternatives, especially in the field of tourism. The financial crisis and economic recession forced households to think about how to better utilise their existing physical assets and how to rein in personal consumption. On the other hand, consumer began being more attentive with their expenses and looking for cheaper alternatives, not only in terms of transport and holidays, but also with respect to grocery shopping and restaurants.

Vacation behaviour changed during the recession [...]. Many leisure travellers opted to take "stay-cations" or regional road trips instead of bigger vacations that involved flying across the country or abroad. According to an index of passenger data from seven top U.S. airlines, passenger traffic fell 12\% during the month of February 2009, the steepest year-over-year decline that we have observed since the aftermath of 9/11 (Olson \& Connor, 2013). 
Smartphone Adoption: the ever-growing diffusion of smartphone, not only among young people, but also across different ages of consumers surely pushed and keep on pushing the diffusion of sharing economy businesses and platforms. The continued growth in smartphone adoption creates indeed a fertile ecosystem for the creation and growth of new business models that usually choose a 'mobile-first' approach. This solution is quite frequent when talking about sharing economy firms, especially concerning transport and leisure. The use of an app rather than a website as the primary point of access for a service has become nowadays a norm rather than an exception.

Digital Payment: the introduction of digital payment is relatively old in many industries. What has recently emerged as an evolution of this system is digital peerto-peer payments, which allows the digital transfer of funds between two people following the completion of a service or the exchange of goods. This new form of digital payment rooted quite easily thanks to a good diffusion of digital payment between consumers and firms, which consumers have already been used to in recent years.

$\square$ Digital peer-to-peer payments represent a critical component to the sharing economy. As a substitute for cash and credit cards, which present the risk of robbery and fraud, digital peer-to-peer payments are a quick and safe way to transfer funds between sharing economy participants (Olson \& Connor, 2013).

Community Culture: to boost the development of sharing platforms, it is very important to build a sense of belonging among users. Reaching this goal is made easy by the diffusion of social networks, which are based on the same idea of community. Nevertheless, this community driven culture must be based on a reputation system, where all users are evaluated by other users and build up their own reliability. This system seems to be strong because the same participant of the platform generates it after they tried the service.

Airbnb's Success: the early success of Airbnb served as a real propeller for several platforms, not only in the industry of accommodation, but also in other various industries. In fact, Airbnb can be identified as the first truly successful experience of a worldwide sharing platform, which arose trustfulness and reliability for these kind of services, stimulating the birth and development of other sharing platforms.

\section{The Airbnb Case}

$\square$ Uber, the world's largest taxi company, owns no vehicles. Facebook, the world's most popular media owner, creates no content. Alibaba, the most valuable retailer, has no inventory. And Airbnb, the world's largest accommodation provider, owns no real estate. Something interesting is happening (Goodwin, 2015).

Airbnb (born as Airbed \& Breakfast) was founded in 2008 in San Francisco, CA. The two founders, experiencing trouble to afford their rent, decided to turn their 
living room into a lodging space with three airbeds on the floor and provide homecooked breakfast in the morning. After eight years, in 2016, it operates in more than 34k towns on 191 Countries. The total amount of listings (apartments, rooms and beds) exceeds 2M announces. In September 2016, Airbnb reached a company valuation that exceeds $\$ 30$ billion, making it the second most valuable start-up in the world, after Uber (Farrell \& Bensinger, 2016).

Just to make a quick comparison, the number of hotels resulted from the merger between Marriott and Starwood is around 5500, offering together more than 1,1M rooms (Hotel News Now, 2015).

Airbnb's business model is relatively simple and consists of three elements: hosts, listings and guests.

Hosts list their property on the platform and establish their own nightly, weekly or monthly price, and offer accommodations to guests.

Listings - properties - may include entire apartments, private rooms or shared rooms. The 'host' of a space may be living there at the time of the rental, as with a typical bed and breakfast (B\&B), or may be absent, possibly away on vacation or even operating the space as a permanent rental. Airbnb claims that $57 \%$ of its listed spaces are entire apartments and homes, $41 \%$ are private rooms, and $2 \%$ are shared rooms (Guttentag, 2015).

Guests are required to interact with hosts directly through the platform for any questions regarding the property. When a potential guest puts in a reservation request, hosts have at least 24 hours to accept or decline it.

Website registration and listings are completely free of charge. Airbnb derives revenue from both guests and hosts for this service: guests pay a 9-12\% service fee for each reservation they make, depending on the length of their stay, and hosts pay a $3 \%$ service fee to cover the cost of processing payments (Zervas et al, 2016).

According to Choudary (2013), Airbnb's operational success can be traced to a three-pronged strategy, which forms the basis of competition on most platforms:

- Creation of new sources of supply: For the first time, anyone with a spare mattress or room could run their own B\&B.

- Creation of new user behaviours on the demand side: Travellers would have rarely stayed at strangers' apartments in a new city, until Airbnb created an entirely new user behaviour.

- Architecting a strong curation system: To create an environment of trust between travellers and hosts, Airbnb invested in a strong curation mechanism, a process by which they separate the best from the rest: a robust review system that lets each party rate the other.

To reinforce this behaviour, Airbnb has built an online reputation system that enables and encourages participants to rate and review each completed stay. Guests use star ratings to rate features of their stay, while both guests and hosts are encouraged to post public reviews of each stay on the platform (Zervas et al, 2016).

\subsection{Airbnb in Italy}

Italy represents for Airbnb the third market worldwide after United States and France. As for 2016, it offers more than 190k accommodations, 9,5\% of the total number of listings. 
On the other hand, the offer of hotels in Italy in 2016 encompasses about 33k hotels, offering $1 \mathrm{M}$ rooms (ISTAT, 2016).

Such a comparison is of course a rule of thumb, because on the one hand the revenues of the rent is divided among all the householders that participate in the sharing platform, while on the other hand, hotels are usually organised in groups or chains and must bear much higher costs compared to individuals.

Figure 3 shows the distribution of listings and guests across Italy; the left part, in particular, shows the distribution of listings, while the right part is about the distribution of guests, representing respectively the supply and demand of sharing accommodation.

The distribution of listings highlights the relevance of big cities, seacoasts, Tuscany countryside and major lakes. With respect to big cites, a strong presence in the areas of Milan, Rome, Naples, Florence and Bari is clearly evident.

In particular, in the North, the area of Milan is not specifically limited to the city but covers the entire metropolitan area, including Como Lake and Pre-Alps. The other cities in the North showing a quite strong presence are Turin, Venice and Bologna. Furthermore, the major lake of northern Italy, Garda Lake, also shows a quite interesting coverage of listings, as well as Liguria's seacoast.

Central Italy is characterised by the prominent coverage of Tuscany, including both the cities of Florence and Pisa together with the countryside, and by the city of Rome. In addition, a quite strong presence is remarkable in the Adria seacoast.

South of Italy shows a high number of hosts in the cites of Naples and Bari and in the south of Apulia. The two main islands, Sicily and Sardinia, concentrate the majority of listings on the seacoasts, with a quite uniform distribution.

On the other hand, the distribution of guests across Regions shows a result that is quite coherent with the distribution of listings:

- >500,000: Lombardy, Tuscany, Lazio

- 300,001-500,000: Veneto

- 150,001-300,000: Liguria, Sicily, Campania

- 50,001-150,000: Piedmont, Emilia-Romagna, Apulia, Sardinia

- $\quad$ 50,000: other Regions 
Figure 2: Airbnb Listings in Italy and Distribution of Guests by Region, 2016

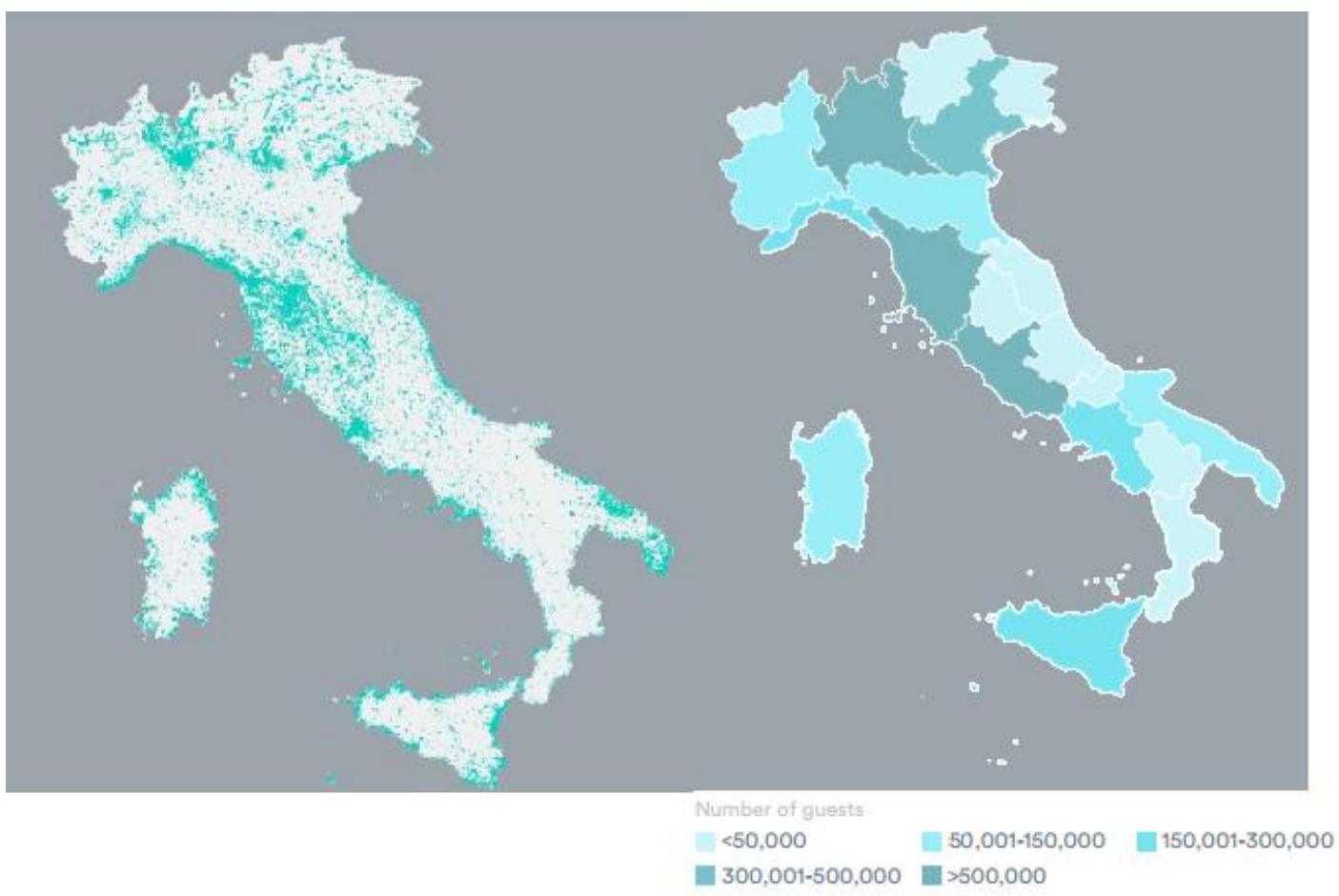

Source: Airbnb, 2016

The distribution of listings and guests, analysed together, shows the match between supply and demand of Airbnb's shared accommodation and remarks on the one hand, the importance of big cities as preferred destinations for tourists, alongside a still strong importance of seacoasts. On the other hand, the density of offer within big cities appears superior to the offer on traditional tourism destinations, i.e. seacoasts. The only traditional destination that remain strong also in the sharing accommodation model is Tuscany countryside, where traditional and shared accommodation coexist and compete.

In order to better understand the importance of big cities in the sharing accommodation model, a special focus on Rome and Milan is useful. Figure 3 shows the distribution of listings within the two major Italian cities, devised by neighbourhoods. Figure 4 shows a comparison between the two cities in terms of Airbnb hosts and guests. 
Figure 3: Airbnb in Rome and Milan, 2016
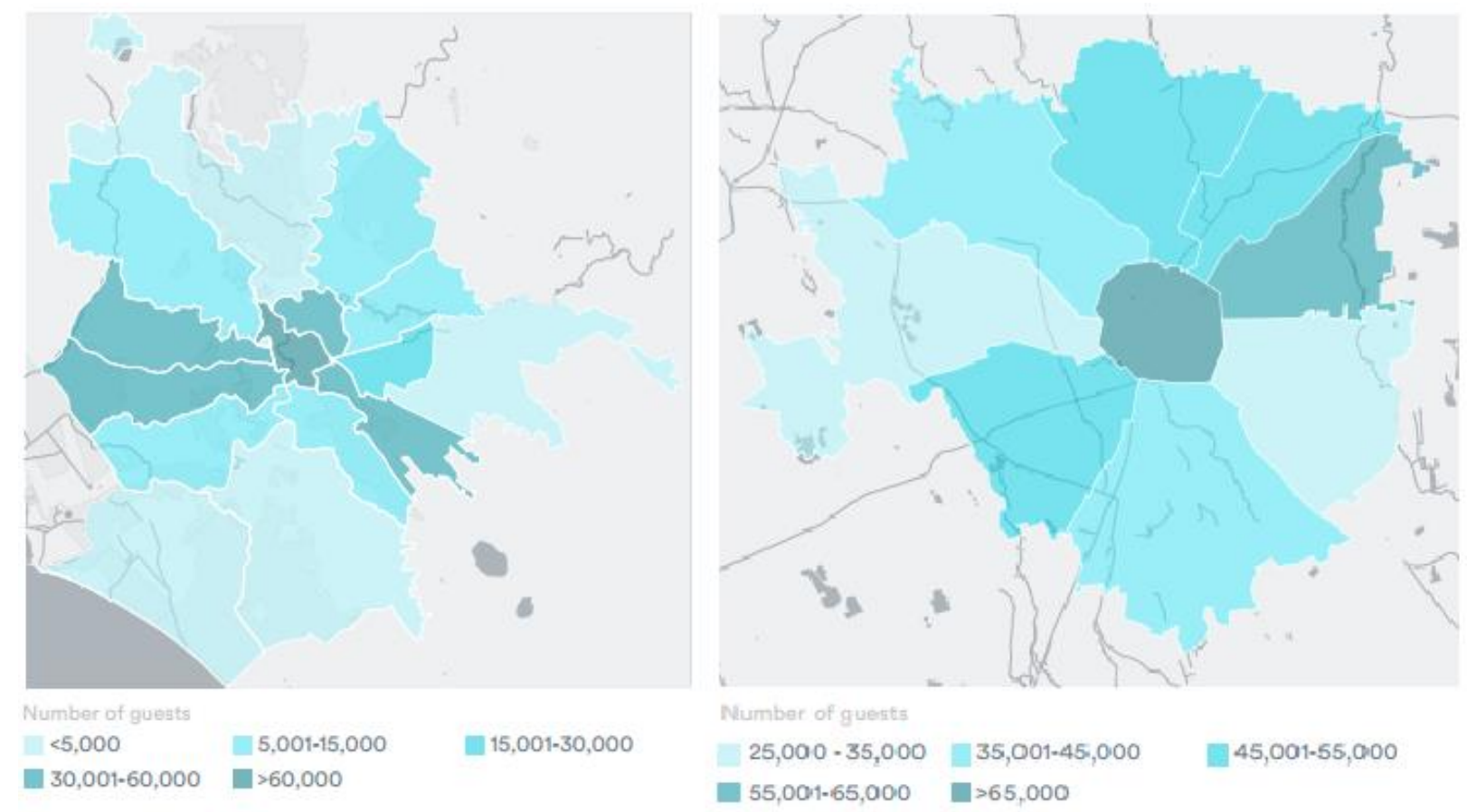

Source: Airbnb, 2016

Figure 4: Airbnb Hosts and Guests in Rome and Milan, 2016

\begin{tabular}{|l|l|l|}
\hline & Rome & Milan \\
\hline Area & $1,285 \mathrm{~km}^{2}$ & $181.76 \mathrm{~km}^{2}$ \\
\hline Population & $2,869,461$ & $1,359,905$ \\
\hline & & \\
\hline Airbnb Hosts & 9,900 & 9,600 \\
\hline Airbnb Guests & 758,000 & 456,000 \\
\hline
\end{tabular}

Source: Airbnb, 2016

The left part of Figure 3 shows the distribution of guests in the city of Rome. As pictured, the most attractive neighbourhoods are Rome I (Historical Centre), Rome II (Parioli/Nomentano), Rome VIII (Appia Antica), Rome XII (Monte Verde) and Roma XIII (Aurelia). In particular, Rome I has more than 60,000 guests and the other cited zones have between 30,001 and 60,000. All other zones have less than 30,000 guests.

The right part of Figure 3, instead, shows the distribution of guests in the city of Milan. The most attractive neighbourhoods are Municipio 1 (Historical Centre), Municipio 3 (Città Studi, Lambate, Porta Venezia), Municipio 2 (Stazione Centrale, Greco, Crescenzago), Municipio 6 (Barona, Lorenteggio) and Municipio 9 (Stazione Garibladi, Niguarda). Municipio 1 has more than 65,000 guests, Municipio 3 has between 55,001 and 60,000 guests and the other cited Municipi have between 45,001 and 55,000 guests. All other zones have less than 45,000 guests. 
A first analysis about the distribution of guests in the two cities suggests that tourists in Rome are much more concentred in the historical centre, while in Milan they are more spread in the various neighbourhoods. Nevertheless, the strongest presence is still remarkable in the historical centre. This is a characteristic that was discovered for other European cities with a high number of tourists like Barcelona (Gutierrez et al., 2017).

Matching these data with those presented in Figure 5, further considerations arise. Figure 4, indeed, shows the total amount of hosts and guests in the two cities. As for the guests, data show a stronger presence in the city of Rome (758,000 guests), concentrated in the historical centre. The number of guests in the city of Milan $(456,000)$ is, on the one hand, minor compared to the number of Rome but, on the other hand, more distributed through the city. As for the hosts, the numbers of Rome and Milan appear quite similar (9,900 Vs 9,600), despite a huge difference between the cities in terms of population and area. Rome has indeed more than twotimes the population of Milan, and a seven-time bigger area (data about population and area refer to the municipality and do not consider suburbs and province).

\subsection{Airbnb in Romania}

Despite a slight recovery after the economic crisis over recent years, Romania's population is still one of the poorest in Europe. Travel \& Tourism can be a catalyst for improving livelihoods throughout the country (Candrea, 2013) and has been identified as such by Romania's leaders as a focal point of the country's National Development Plan. Despite being a communist country, during the 1970s and beginning of the 1980s, Romania managed to attract an important number of foreign tourists through affordable accommodation and an adequate level of quality (Pop, 2014). The Romanian tourism accommodation supply is still based on infrastucture built mainly in 1970s for mass tourism, one of the reasons that it is unattractive and uncompetitive on the international market (Coroș \& Negrușa, 2014). In spite of this conclusion drawn based on the quality of accommodation offering, Romania become present on different tourism recommandations for international travellers. For example, Lonely Planet included Transylvania as one of its top 10 destinations for 2016 (Kane, 2015). An important part of Romania's and Transylvania's natural and cultural heritage is hosted in rural destinations which lack of proper infrastructure (Coroș \& Negrușa, 2014).

For the tourists who appreciate simple travels, accomodations and food services, Romanian pensions located in rural regions will thrive if they will be able to identify appropriate promotional actions (Baltescu, 2015). According to Coroș and Negrușa (2014), who cited an analysis realized by practitioners, in Romania were functioning over 8,000 pensions, offering approximately 140,000 beds in the middle of 2012, and only less than half were classified. So, it can be stated that five years ago thousands of listings and ten thousands of beds was offered without being on official system of classification for tourism accommodation units. These estimated data could be a starting point about evaluation of the potential that eplatforms like Airbnb can have in Romania.

Airbnb doesn't release the Home Sharing Activity Reports for Romania, so its presence in Romania will be analysed in correlation with the Romania's position in the global tourism. The comparative analysis with Italy should be seen in the 
context of big data about the tourism in these two countries. For example, in 2016, the direct contribution of the Travel \& Tourism to the GDP was 86,2 billion USD for Italy and 2,5 billion for Romania. As the percent of the GDP, Travel \& Tourism contributed with $4.6 \%$ to the GDP in Italy and 1,3\% in Romania (World Travel \& Tourism Economic Impact, 2017).

According with airbnb.com statistics analyzed by Romanian journal Capital, at the end of 2016, almost 10,000 properties were registered in Romania with prices starting at 10 euro per night for a bed in a shared room to more than 1000 euro per night for a luxurious seven-bedroom villa and pool in the center of Bucharest (www.capital.ro). Beyond numbers, the Airbnb presence in Romania could be marked at the symbolic level. At the beginning of October 2016, Airbnb announced that Bran Castle in Romania, also known as "Dracula's Castle", would be listed on its website for the night of October 31, and two brave souls had the chance to spend Halloween in the imposing medieval fortress, which is located in the Carpathian mountains of Transylvania. Airbnb ran a global competition to win the spooky stay (Meltzer, 2016).

For the purpose of this study, two destinations from Romania was considered: Bucharest (the capital and Romania), and Brasov (the second destination after Bucharest based on foreign tourists).

Figure 5: Statistic for official tourism accredited accommodation at 31.07.2016

\begin{tabular}{|l|l|l|l|l|l|l|}
\hline & $\begin{array}{l}\text { Number of } \\
\text { buildings } \\
\text { for tourism } \\
\text { accommoda } \\
\text { tion }\end{array}$ & $\begin{array}{l}\text { Number of } \\
\text { rooms for } \\
\text { tourism } \\
\text { accommoda } \\
\text { tion }\end{array}$ & $\begin{array}{l}\text { Numb } \\
\text { er of } \\
\text { hotels }\end{array}$ & $\begin{array}{l}\text { Numb } \\
\text { er of } \\
\text { hotel } \\
\text { rooms }\end{array}$ & $\begin{array}{l}\text { Other types } \\
\text { of buildings } \\
\text { for } \\
\text { accommoda } \\
\text { tion (hostel, } \\
\text { motel, } \\
\text { villas, } \\
\text { chalets) }\end{array}$ & $\begin{array}{l}\text { Number of } \\
\text { rooms in } \\
\text { other type } \\
\text { of } \\
\text { accommoda } \\
\text { tion }\end{array}$ \\
\hline $\begin{array}{l}\text { Total } \\
\text { Roman } \\
\text { ia }\end{array}$ & 6946 & 149280 & 1551 & 95186 & 5395 & 54094 \\
\hline $\begin{array}{l}\text { Buchar } \\
\text { est }\end{array}$ & 149 & 10231 & 123 & 9892 & 26 & 339 \\
\hline $\begin{array}{l}\text { Brasov } \\
\text { county }\end{array}$ & 881 & 12828 & 122 & 5345 & 759 & 7483 \\
\hline
\end{tabular}

Source: Romanian National Statistic report for Tourism, 2016

Figure 6 shows a comparison between the cities of Brasov and Bucharest in terms of hosts and rentals based on data available on www.airdna.co at the end of June 2017. The impact of sharing economy platforms on Romanian tourism industry could be higher than in the more mature markets since the importance of digital marketing seems to be little understood by the Romanian hoteliers and Romanian hotel owners and/or managers do not acknowledge the business environmental changes brought by Airbnb (Cojocea and Coroș, 2014). 
Figure 6: Airbnb hosts and rentals, June 2017

\begin{tabular}{|l|l|l|}
\hline & Bucharest & Brasov \\
\hline Area & $228 \mathrm{~km}^{2}$ & $74 \mathrm{~km}^{2}$ \\
\hline Population & 1.883 .425 & 253.200 \\
\hline & & \\
\hline Airbnb active hosts & 1233 & 356 \\
\hline $\begin{array}{l}\text { Airbnb multiple listing } \\
\text { hosts }\end{array}$ & 286 & 104 \\
\hline Airbnb superhosts & 155 & 72 \\
\hline & & 586 \\
\hline Airbnb active rentals & 2255 & 158 \\
\hline $\begin{array}{l}\text { Airbnb properties with } \\
\text { 10 or more reviewers }\end{array}$ & 559 & 269 \\
\hline $\begin{array}{l}\text { Airbnb properties rated } \\
\text { 5 stars }\end{array}$ & 701 & \\
\hline
\end{tabular}

Source: Airdna.co, Wikipedia.org

\section{Conclusions and Emerging Issues}

Airbnb started to strongly influence the way of doing business in the hotel industry because of the innovation and rapid adoption of new ICT technologies in the communication and booking. Benjamin Habbel, the founder of Voyat, an ecommerce optimization platform, pointed the fact that "hotels need to steal basic things out of the Airbnb and online travel agency playbooks, like making their webpages load quickly on mobile devices and reducing the number of clicks it takes to finalize a transaction." (O’Neil, 2017).

Another issue related with the presence of Airbnb on the analyzed markets is about the (in)existing conflict between the unregulated accommodation provided and mediated by the platform and local regulators and residents. Since Romanian laws are not clear about the way of regulate and tax the emerging activity of small properties rented for tourists, a mature touristic market like the Italian one have to deal with new issues like "over-tourism" and fair competion with the established hotel industry.

As Airbnb has always defined its core audience, "head-first explorers", as a psychographic consumer segment that drives their business, the traditional hotel industry should find smart communication strategies in order to target younger millennials, which have "the tendency to value experiences over things had become a global mindset that crossed geographies and demographics."(Mildenhall, 2017).

\section{Bibliography}

Airbnb (2016) Overview of the Airbnb Community in Italy, Corporate Report.

Airbnb (2017). How do I become a Superhost, https://www.airbnb.com/help/article/829/how-do-ibecome-a-superhost

Amariei, R. (2016). Uber și Airbnb împart România în două. 
http://www.capital.ro/uber-si-airbnb-impart-romania-in-doua.html?\&page=2

Arrigo, E. (2006). Code of Conduct and Corporate Governance. Symphonya, Emerging Issues in Management (symphonya.unimib.it), (1), 93-109.

http://dx.doi.org/10.4468/2006.1.07arrigo

Baltescu, C. A. (2015). Trends driving the hotel industry global evolution. Case of Romania. Bulletin of the Transilvania University of Brasov. Economic Sciences. Series V, 8(1), 81.

Belk, R. (2014). You are what you can access: Sharing and collaborative consumption online, Journal of Business Research, 67, 1595-1600.

http://dx.doi.org/10.1016/j.jbusres.2013.10.001

Bellini, N. (2015). Smart Specialisation in Europe: Looking Beyond Regional Borders, Symphonya. Emerging Issues in Management (symphonya.unimib.it), 1, 22-29.

http://dx.doi.org/10.4468/2015.1.03bellini

Botsman, R. (2012). The currency of the new economy is trust. Speech delivered at TED Global, June 2012.

https://www.ted.com/talks/rachel_botsman_the_currency_of_the_new_economy_is_trust

Brondoni, S. M. (2016). Global Tourism Management. Mass, Experience and Sensations Tourism, Symphonya. Emerging Issues in Management (symphonya.unimib.it), 1, 7-24.

http://dx.doi.org/10.4468/2016.1.02brondoni

Brondoni, S. M. (2014). Global Capitalism and Sustainable Growth. From Global Products to Network Globalisation, Symphonya. Emerging Issues in Management (symphonya.unimib.it), 1, $10-31$.

http://dx.doi.org/10.4468/2014.1.02brondoni

Brondoni, S. M. (2011). Global Networks, Knowledge Management and World Cities, Symphonya. Emerging Issues in Management (symphonya.unimib.it), 1, 7-18.

http://dx.doi.org/10.4468/2011.1.02brondoni

Candrea, A.N., Ecotourism development in Romania, a possible contribution to the fulfillment of the real convergence criteria for euro adoption, Bulletin of the Transilvania University of Braşov, Series V: Economic Sciences, Vol. 6 (55), No. 1, 2013, pp. 89-96.

Cesarani, M. (2014). Competitive Dimension of Outsourcing Relations in Global Networks. Journal of Management Policies and Practices, 2(4), 97-112.

http://dx.doi.org/10.15640/jmpp.v2n4a5

Cheng, M. (2016). Sharing economy: A review and agenda for future research, International Journal of Hospitality Management, 57, 60-70.

http://dx.doi.org/10.1016/j.ijhm.2016.06.003

Choudary, S. P. (2013). The AirBnB Advantage: How to avoid competition and become a multibillion dollar startup, The Next Web, 10 Mar. 2013.

Christensen, C. M., Raynor, M. E., \& McDonald, R. (2015). Disruptive innovation. Harvard Business Review, 93(12), 44-53.

Cojocea, M. L., \& Coroș, M. (2014). Romanian Hotels in the Digital Marketing Present. Studia Universitatis Babes-Bolyai, Negotia, 59(3).

Coros, M. M., \& Negrusa, A. L. (2014). Analysis of Romania's and Transylvania's tourist supply development and performance. Amfiteatru Economic, 16(8), 1312.

Cusumano, M. A. (2015). How Traditional Firms Must Compete in the Sharing Economy, Communications of the ACM, 58 (1), 32-34.

http://dx.doi.org/10.1145/2688487

Davidson, N. M. \& Infranca, J. (2016). The Sharing Economy as an Urban Phenomenon, Yale Law \& Policy Review, 34(2), Fordham Law Legal Studies Research Paper No. 2802907; Suffolk University Law School.

Dredge, D. \& Gyimòthy, S. (2015). The collaborative economy and tourism: Critical perspectives, questionable claims and silenced voices, Tourism Recreation Research, 40(3), 286-302. 
http://dx.doi.org/10.1080/02508281.2015.1086076

Farrell, M. \& Bensinger, G. (2016). Airbnb's Funding Round Led by Google Capital, The Wall Street Journal, 22 Sept. 2016.

Forno, F. \& Garibaldi, R. (2015). Sharing Economy in Travel and Tourism: The Case of HomeSwapping in Italy, Journal of Quality Assurance in Hospitality \& Tourism, 16(2), 202-220. http://dx.doi.org/10.1080/1528008X.2015.1013409

Frenken, K. Meelen, T., Arets, M. \& P. Van de Glind (2015). Smarter regulation for the sharing economy' The Guardian, blog.

Goodwin, T. (2015). The Battle Is for The Customer Interface, TechCrunch, 3 Mar. 2015.

Gotham, K. F. (2005). Tourism gentrification: The case of new Orleans' vieux carre (French Quarter). Urban studies, 42(7), 1099-1121.

http://dx.doi.org/10.1080/00420980500120881

Goudin Pierre (2016). The Cost of Non-Europe in the Sharing Economy, European Parliamentary Research Service.

http://dx.doi.org/10.2861/26238

Gutiérrez, J., García-Palomares, J. C., Romanillos, G., \& Salas-Olmedo, M. H. (2017). The eruption of Airbnb in tourist cities: Comparing spatial patterns of hotels and peer-to-peer accommodation in Barcelona. Tourism Management, 62, 278-291.

https://doi.org/10.1016/j.tourman.2017.05.003

Guttentag, D. (2015). Airbnb: disruptive innovation and the rise of an informal tourism accommodation sector, Current Issues in Tourism, 18(12), 1192-1217.

http://dx.doi.org/10.1080/13683500.2013.827159

Guttentag, D. A., \& Smith, S. L. (2017). Assessing Airbnb as a disruptive innovation relative to hotels: Substitution and comparative performance expectations, International Journal of Hospitality Management, 64, 1-10.

https://doi.org/10.1016/j.ijhm.2017.02.003

J. Walter Thompson Intelligence, (2015). The sharing economy prosumer. https://www.jwtintelligence.com/2015/06/the-sharing-economy-prosumer/

Henten A. H. \& Windekilde, I. M. (2016). Transaction costs and the sharing economy, info, 18(1), $1-15$.

http://dx.doi.org/10.1108/info-09-2015-0044

Hotel News Now (2015) The 10 largest hotel companies by room count, 19 Nov. 2015.

Kane, C. (2015). Lonely Planet says these are the Top 10 countries to visit in 2016.

http://fortune.com/2015/11/07/top-countries-lonely-planet/

Lane, J., \& Woodworth, R. M. (2016). The sharing economy checks in: An analysis of Airbnb in the United States. CBRE Hotel's Americas Research.

http://rss.hsyndicate.com/file/152006265.pdf

Meleo, L., Romolini, A. \& De Marco, M. (2016). The Sharing Economy Revolution and Peer-topeer Online Platforms. The Case of Airbnb, Exploring Science Services, Springer International Publishing Switzerland http://dx.doi.org/10.1007/978-3-319-32689-4 43

Meltzer, H. (2016). Airbnb hosted a night in Dracula's Transylvanian castle on Halloween http://www.telegraph.co.uk/travel/destinations/europe/romania/articles/airbnb-is-offering-anight-in-dracula-castle-halloween/

Mildenhall, J. (2017). How Airbnb built its brand by telling the world not to travel.

http://www.campaignlive.co.uk/article/airbnb-built-its-brand-telling-world-not-travel/1444657

Neuts, B., \& Nijkamp, P. (2012). Tourist crowding perception and acceptability in cities: An applied modelling study on Bruges. Annals of Tourism Research, 39(4), 2133-2153.

https://doi.org/10.1016/j.annals.2012.07.016

Olson M. J. \& Connor A. D (2013). The Disrutpion of Sharing, PiperJaffray

O'Neil, S. (2017). Hotels may try to counter Airbnb's rise with bets on tech. 
https://skift.com/2017/08/14/hotels-may-try-to-counter-airbnbs-rise-with-bets-on-tech

Paulauskaite, D., Powell, R., Coca- Stefaniak, J. A., \& Morrison, A. M. (2017). Living like a local: Authentic tourism experiences and the sharing economy. International Journal of Tourism Research.

http://dx.doi.org/10.1002/jtr.2134

Pine, B. J., \& Gilmore, J. H. (1998). Welcome to the experience economy. Harvard Business Review, 76, 97-105.

Pop, C. (2014). The Current Profile of Romanian Hotel Industry: Does It Enhance the Attractiveness of Romania as a Tourist Destination?. Studia Universitatis Babes-Bolyai, Negotia, 59(3).

Riboldazzi, S. (2015). R\&D and Product Engineering in Global Pharmaceutical Companies, Symphonya. Emerging Issues in Management (symphonya.unimib.it), 2, 57-74.

http://dx.doi.org/10.4468/2015.2.05riboldazzi

Richard, B. \& Cleveland, S. (2016). The future of hotel chains: Branded marketplaces driven by the sharing economy, Journal of Vacation Marketing, 22(3), 239-248.

http://dx.doi.org/10.1177/1356766715623827

Romanian National Statistic report for Tourism, 2016

http://www.insse.ro/cms/sites/default/files/field/publicatii/capacitatea de cazare turistica_existen ta_la_31_iul_2016.pdf

Russo, M., \& Cesarani, M. (2017). Strategic Alliance Success Factors: A Literature Review on Alliance Lifecycle, International Journal of Business Administration, 8(3), 1-9.

http://dx.doi.org/ 10.5430/ijba.v8n3p1

Salvioni, D. M. (2016). Hotel Chains and the Sharing Economy in Global Tourism, Symphonya. Emerging Issues in Management (symphonya.unimib.it), 1, 31-44.

http://dx.doi.org/10.4468/2016.1.04salvioni

Täuscher, K., \& Laudien, S. M. (2017). Understanding platform business models: A mixed methods study of marketplaces. European Management Journal.

http://dx.doi.org/10.1016/j.emj.2017.06.005

The Economist (2017). Airbnb: A different breed of unicorn, print edition May 27th - June 2nd 2017

Tussyadiah, I. P., \& Pesonen, J. (2016). Impacts of peer-to-peer accommodation use on travel patterns. Journal of Travel Research, 55(8), 1022-1040.

http://dx.doi.org/10.1177/0047287515608505

Varma, Arup, et al. "Airbnb: Exciting innovation or passing fad?." Tourism Management Perspectives 20 (2016): 228-237. https://doi.org/10.1016/j.tmp.2016.09.002

Weston R. (2015) Research for Tran Committee - Tourism and The Sharing Economy: Challenges and Opportunities for The EU, Directorate General for Internal Policies.

http://dx.doi.org/10.2861/965550

World Travel \& Tourism Economic Impact 2017

https://www.wttc.org/research/economic-research/economic-impact-analysis/country-reports/

Yannopoulou, Natalia, Mona Moufahim, and Xuemei Bian. "User-generated brands and social media: Couchsurfing and AirBnb." Contemporary Management Research 9.1 (2013): 85.

http://dx.doi.org/10.7903/cmr.11116

Zervas, G., Proserpio, D. \& Byers, J. W. (2016). The Rise of Sharing Economy: Estimating the Impact of Airbnb on the Hotel Industry, Boston U. School of Management Research Paper.

http://dx.doi.org/10.2139/ssrn.2366898 